\title{
Quality Analysis Of Management Information System And Work Environment To Employee Performance
}

\author{
Siti Rahmayuni \\ Management \\ Institute of Economic Science Balikpapan \\ Balikpapan City \\ Email: youni.anwar@yahoo.com
}

\begin{abstract}
This study aims to analyze the problems that occur in Institute of Economic Science Balikpapan, about the relationship between quality management information systems and work environment to employee performance where the quality management information system and adequate working environment can increase profits for the company. The number of respondents used in this study is this study is 60 samples from high school employees of economic background. This step which states how far has been met various requirements, specifications and expectations of an activity to collect, store data, facts and messages opinions and comments, so that employees can know Situations that occur outside of himself Based on the results of regression the biggest influence lies on the variable Quality of information systems while the working environment variables have the lowest value, Institute of Economic Sciences expected to pay attention quality of information systems to improve employee performance
\end{abstract}

Keywords—system; information; management and performance

\section{INTRODUCTION}

Each organization has its own management information system, where the system is very influential on employee performance, with the employee information management system to know the job description, and with the job desk can be seen how the performance of employees in carrying out their activities. Institute of Economic Science Balikpapan is one of the private universities that have management information system and work environment which is almost same with other institution, where there is top management up to low management. A good working environment will have a positive impact on employee performance. This can be seen from job description of employee, and facility and conformity of work is a matter to note Institute of Economic Science Balikpapan is currently improving its information system using ISO 9001: 2015 .

Working environment inside a organization affects employee performance. Environment this work itself consists of physical and nonphysical inherent to employee performance. The physical work environment fresh, comfortable, and meet the standard a worthy need will contribute to employee comfort within do his job. Non-physical work environment which includes the hospitality of employees' attitudes, mutual respect at different times opinions, and so forth is a requirement must continue to foster quality of thought employees who can eventually build performance they are continuous.

Research purposes To know how far the influence of management information system and work environment to employee performance at Institute of Economic Science Balikpapan.

\section{LITERATURE REVIEW}

According to Wikipedia MIS is a system of planning a part of the internal control of a business that includes human utilization, documents, technology, and procedures by management accounting to solve business problems such as product cost, service, or a business strategy. Management information system is distinguished from ordinary information systems because SIM is used to analyze other information systems applied to the operational activities of the organization. Academically, the term is generally used to refer to a group of information management methods 
associated with automation or support for human decision-making, such as decision support systems, expert systems, and executive information systems.

According Jogiyanto (2003: 11). Information system is a system at in a coherent organization daily transaction processing needs, support operations, are managerial and strategic activities of an organization and provide certain outside parties with reports required

According Bodnar (2003) Quality is summarizes characteristics of quality information identified include the following

a. Relevant

Information is said to be relevant if the information can be reduced uncertainty, improving the ability of decision-makers to make predictions, or confirm, or correct their expectations in the future then.

b. Reliable

Information is said to be reliable when it is free of errors and bias, and accurately describe events or organizational activities.

c. Complete

Information is said to be perfect or complete if he does not leave important aspects underlying an event or activity as measured.

d. Timely

Information is said to be times when information is available at the time decision makers use it to make decisions.

e. Understandable

Information is said to be understood when information is presented in a useful and understandable format.

f. Verifiable

Information said to be tested when two people are knowledgeable independently checking, will produce the same information.

According Lewa and Subowo (2005) work environment designed in such a way as to create a working relationship that binds workers to their environment. A good working environment is where employees can perform activities optimally, healthy, safe and comfortable. Inadequate work environments may demand more labor and time and do not support the efficient system of work plans.

According Sedarmayati (2009: 21) the definition of work environment is as follows: "Work environment is the whole tooling tools and materials encountered, the surrounding environment in which a person works, methods of work, and arrangement of work both as individuals and as a group. Type of Work Environment

Sedarmayanti (2009) states that in general, the type of work environment is divided into 2 namely: (a) physical work environment, and (b) non-physical work environment.

A. Physical work environment

According Sedarmayanti (2009) is a physical work environment that is all the physical circumstances that exist around the workplace where it can affect employees either directly or indirectly. The physical work environment itself can be divided into two categories, namely

1. Environment directly related to employees (such as: work centers, chairs, tables and so on)

2. An intermediate environment or common environment may also be called a work environment that affects the human condition, for example: temperature, humidity, air circulation, lighting, noise, mechanical vibration, odor, color, ect

B. Non Physical Work Environment

Sadarmayanti (2009) states that the nonphysical work environment is all the circumstances that occur related to the relationship work, either with superiors or with colleagues, or with subordinates. This non-physical environment is also a group of work environments that can not be ignored.

There are 5 aspects of non physical work environment according to (Sedamayanti, 2001) can affect employee behavior, namely:

a. The structure of work, namely the extent to which that work is given to him has a good work structure and organization.

b. Job responsibility, ie the extent to which workers feel that work understands their responsibilities and is responsible for their actions.

c. Attention and leader support, ie the extent to which employees feel that leaders often give direction, confidence, concern and appreciation.

d. Cooperation between groups, namely the extent to which employees feel there good cooperation among existing working groups.

e.Smooth communication, ie the extent to which employees feel good communication, open, and smooth, both between friends work or with leadership. Both types of work environment 
above should always be considered by the organization. Both are inseparable just like that.

The problem of work environment in an organization is very important, in this case required the arrangement and arrangement of factors - factors physical work environment in organizing organizational activities

According to Widodo (2006: 78) said that the performance is to perform an activity and refine it in accordance with its responsibilities with the results as expected. From the above definition of performance is more emphasis on responsibility with the expected results.

According to Mahsun (2006: 25) performance (performance) is a description of the level of achievement of the implementation of an activity / program / policy in realizing the goals, objectives, mission and vision of the organization contained in strategic planning of an organization

Influence Between Quality Management Information Systems Against Employee performance is namely the existence of management information system automatically employees know how the work and results obtained, dang with the existence of the system then the work environment is also a supporter of employee performance

\section{RESEARCH METHODOLOGY}

This research uses descriptive data analysis where the hypothesis testing using questionnaires and interviews directly. This analysis is done to get descriptive picture about respondents of this study, especially regarding the research variables used. This analysis is performed using index analysis techniques for describes the respondent's perception of the items of the question being asked

\section{FINDING AND DISCUSSION}

Use of information systems have a significant effect on work motivation, the magnitude of the influence of the use of information systems on employee performance $(0.476) 2=0.226$ or $22.6 \%$. Work environment is influential significant to employee performance Magnitude the influence of work environment on employee performance is equal to $(0,334) 2=0.111$ or $11.1 \%$.

\section{CONCLUSION}

1.The use of information systems is influential significant to employee performance, then hypothesis "the use of information systems significant effect on employee performance "is acceptable.

2.Work environment has significant effect on employee performance. Hypothesis "work environment have a significant effect on motivation work "is acceptable

\section{SUGGESTION}

1.Based on the results of the hypothesis that the management information system has an effect on the employee performance, then the head of high school of economics should use the system

2.Work environment also has a significant effect on employee performance so it must be considered for the purpose of the institution is achieved

\section{REFERENCE}

Brantas. 2009. Fundamentals of Management. Bandung: Alfabeta.

Gomes Faustino Cardoso. 2003. Source Management

Human Power, Yogyakarta: Andi Offset, Jogiyanto, HM. 2003. Information Technology System. Issue 1. Yogyakarta: ANDI.

Riduwan. 2010. How to Use and Meaning Path Analysis. Bandung: Alfabeta.

Sedarmayanti. 2001. Human Resources and Work productivity. Bandung: Mandar Advanced. 